\title{
Catalytic Properties of Alumina-Supported Ruthenium, Platinum, and Cobalt Nanoparticles towards the Oxidation of Cyclohexane to Cyclohexanol and Cyclohexanone
}

\author{
Ilhem Rekkab-Hammoumraoui*, Abderrahim Choukchou-Braham \\ Laboratoire de Catalyse et Synthèse en Chimie Organique, Faculté des Sciences, \\ Université de Tlemcen, Algeria
}

Received: 26 ${ }^{\text {th }}$ May 2017; Revised: 17th July 2017; Accepted: 18th July 2017

Available online: 22 $2^{\text {nd }}$ January 2018; Published regularly: $2^{\text {nd }}$ April 2018

\section{Abstract}

A series of metal-loaded ( $\mathrm{Ru}, \mathrm{Pt}, \mathrm{Co})$ alumina catalysts were evaluated for the catalytic oxidation of cyclohexane using tertbutylhydroperoxide (TBHP) as oxidant and acetonitrile or acetic acid as solvent. These materials were prepared by the impregnation method and then characterized by Inductively Coupled Plasma-Optical Emission Spectroscopy (ICP-OES), $\mathrm{H}_{2}$ chemisorption, Fourier Transformed Infrared Spectroscopy (FTIR), High-Resolution Transmission Electron Microscopy (HRTEM), and X-ray Diffraction (XRD). All the prepared materials acted as efficient catalysts. Among them, $\mathrm{Ru} / \mathrm{Al}_{2} \mathrm{O}_{3}$ was found to have the best catalytic activity with enhanced cyclohexane conversion of $36 \%$, selectivity to cyclohexanol and cyclohexanone of $96 \%(57.6 \mathrm{mmol})$, and cyclohexane turnover frequency (TOF) of 288 $\mathrm{h}^{-1}$. Copyright (c) 2018 BCREC Group. All rights reserved

Keywords: Cyclohexane oxidation; Alumina-supported; ruthenium; platinum; cobalt; TBHP

How to Cite: Rekkab-Hammoumraoui, I., Choukchou-Braham, A. (2018). Catalytic Properties of Alumina-Supported Ruthenium, Platinum, and Cobalt Nanoparticles towards the Oxidation of Cyclohexane to Cyclohexanol and Cyclohexanone. Bulletin of Chemical Reaction Engineering \& Catalysis, 13(1): 24-36 (doi:10.9767/bcrec.13.1.1226.24-35)

Permalink/DOI: https://doi.org/10.9767/bcrec.13.1.1226.24-35

\section{Introduction}

The oxidation of organic substrates represents one of the most important industrial chemical reactions [1]. This explains the significant effort invested in research and development of new heterogeneous catalysts with increased activities and selectivities in these types of reactions. In particular, cyclohexane oxidation is one of the main goals in this area. The oxidation of cyclohexane to cyclohexanol and cyclohexanone is a key reaction in the syn-

* Corresponding Author.

E-mail: rekkabilhem@yahoo.fr (Rekkab-Hammoumraoui, I.)) thesis of adipic acid (AA), which is an extremely important commodity chemical [2,3] mainly used in the production of urethanes and nylon6,6 (for fibers and resins). The global AA capacity, produced in 2006, was around 2.8 million metric tons and the demand for it has been growing, year after year, in the last decade [4]. The contemporary industrial process for manufacturing adipic acids (AA) is a two-step process involving nitric acid oxidation of KA oils, a mixture of cyclohexanol and cyclohexanone (which is produced from cyclohexane) using a homogeneous cobalt-based catalyst $[5,6]$. The main disadvantage of this process is that large amounts 
of nitrous oxide $\left(\mathrm{N}_{2} \mathrm{O}\right)$ are released causing global warming and ozone depletion as well as acid rain and smog. Therefore, it is highly desirable to develop an alternate and effective green synthetic route for AA that is environmentally friendly [7-9].

Over the last decade, the research and development of transition metal nanoparticles have received a great deal of attention in many areas of science due to the fact that nanosized particles show different physical and chemical properties compared to those of the same materials in the bulk [10-13]. In recent years, many catalysts have been used for cyclohexane oxidation. For example, the catalytic oxidation of cyclohexane by $\mathrm{O}_{2}$ over $\mathrm{Au}-\mathrm{Pd} / \mathrm{MgO}$ was reported by Liu et al. [14], in which conversion of $11 \%$ and selectivity of $90.7 \%$ were obtained, at $413 \mathrm{~K}$ and 3 bar $\mathrm{O}_{2}$.

A series of cobalt-doped vanadium phosphorus oxides (VPO-Co) was synthesized by Mahdavi et al. [15] and used as catalysts in liquid oxidation of cyclohexane, with tertbutylhydroperoxide (TBHP) as oxidant; the conversion obtained was $65 \%$ and the selectivity of cyclohexanol and cyclohexanone was $53 \%$, with reaction time of $8 \mathrm{~h}$. Makgwane et al. [16] developed a hetero-mixed tungsten-vanadia $\left(\mathrm{WO}_{3} / \mathrm{V}_{2} \mathrm{O}_{5}\right)$ catalyst for cyclohexane oxidation, by using $\mathrm{H}_{2} \mathrm{O}_{2}$. Conversions up to $90 \%$ were reached, while the total selectivity toward cyclohexanol and cyclohexanone was found around $65 \%$. In another study, Bellifa et al. [17] reported that vanadium-titanium and chromium- titanium mixed oxides MTiX ( $\mathrm{M}=$ $\mathrm{Cr}$ and V) can catalyze the oxidation of cyclohexane using TBHP. The best result was obtained by $\mathrm{V}-\mathrm{TiO}_{2}$, with conversion of $35 \%$ and olone selectivity of $92 \%$.

Hayati et al. [18] have used titanium modified octahedral manganese oxide Ti-OMS-2 in the oxidation of cyclohexane. They suggest that both titanium sites in frame-work and nonframework and the Lewis acidity created by the impregnation of $\mathrm{Ti}$, increased the activity of OMS-2 in oxidation reactions. The conversion and selectivity of cyclohexanol and cyclohexanone are in the range of 4.4-7.8 and 89-92\%, respectively. On the other hand, Carabineiro et al. [19] tested gold nanoparticles supported on carbon materials for the oxidation of cyclohexane to cyclohexanol and cyclohexanone, under mild conditions (room temperature and atmospheric pressure), using an environmentally friendly oxidant $\left(\mathrm{H}_{2} \mathrm{O}_{2}\right)$. The conversion was 3.6 $\%$ and the selectivity of cyclohexanol and cyclohexanone was $98 \%$.
Huang et al. [20] conducted a series of studies on cyclohexane by air oxidation; using boehmite $((\mathrm{AlOOH})$ immobilized cobalt tetra (4 carboxyl) phenylporphyrin catalyst (CoTCPP). Cyclohexane conversion of $19.6 \%$ and selectivity of $73 \%$ were obtained. $\mathrm{Lu}$ et al. [21] reported a $9.2 \%$ conversion and $92.7 \%$ selectivity when $\mathrm{Co}_{3} \mathrm{O}_{4}$ catalyst was used for the oxidation of cyclohexane with $\mathrm{O}_{2}$, at $130{ }^{\circ} \mathrm{C}$. Ti-Zr-Co alloys were prepared by Hao et al. [2], and then used as catalysts in solvent-free liquid phase oxidation of cyclohexane by oxygen; the conversion obtained was $6.8 \%$ and the selectivity of cyclohexanol and cyclohexanone was $90.4 \%$.

In our present work, ruthenium, platinum and cobalt nanoparticles supported on alumina were used as catalysts for the aerobic oxidation of cyclohexane to KA oils (i.e., cyclohexanone and cyclohexanol), giving moderate yields and improved catalyst turnover number. Noble metals $(\mathrm{Ru}, \mathrm{Pt})$ are much active, stable and selective. They are widely used because of their better performance in many oxidation reactions. Cobalt was chosen due to it prevalent use in many oxidations, including that of cyclohexane commercially.

\section{Materials and Methods}

\subsection{Catalyst preparation}

\subsubsection{Starting materials}

The following chemicals were employed for the preparation of catalysts and in catalytic testing, namely $\mathrm{Al}_{2} \mathrm{O}_{3}$ (Oxid $\mathrm{C}$ Degussa), $\mathrm{Co}\left(\mathrm{NO}_{3}\right)_{2} \cdot 6 \mathrm{H}_{2} \mathrm{O}$ (Fluka), $\mathrm{Pt}\left(\mathrm{NH}_{3}\right)_{2}\left(\mathrm{NO}_{2}\right)_{2}$ (Alfa Aesar), $\mathrm{Ru}(\mathrm{acac})_{3}$ (Strem Chemicals), tertiobutyl hydroperoxide (TBHP, Aldrich, $70 \%$ in water), Cyclohexane (Prolabo), Acetonitrile (Aldrich), Acetic Acid (Aldrich), Triphenylephosphine (Aldrich).

\subsubsection{Synthesis}

The $\mathrm{Al}_{2} \mathrm{O}_{3}$ support of commercial grade was purchased in the form of nanopowder (in the range $10-50 \mathrm{~nm}$ ). It required further treatment before impregnation of the metal precursors. The support was mixed with water $(200 \mathrm{~mL}$ of $\mathrm{H}_{2} \mathrm{O}$ for $100 \mathrm{~g}$ of support) in order to form a paste, which was dried overnight at $120^{\circ} \mathrm{C}$, and then sieved to retain only the particles having a diameter ranging between 0.1 and $0.25 \mathrm{~mm}$. Then the support underwent calcination at $400{ }^{\circ} \mathrm{C}$ under oxidative flow $\left(20 \% \mathrm{O}_{2}\right.$, $80 \% \mathrm{Ar}, 60 \mathrm{~mL} / \mathrm{min}$ ), during $4 \mathrm{~h}$. After activation, $\mathrm{Al}_{2} \mathrm{O}_{3}$ showed a BET specific surface area of $95 \mathrm{~m}^{2} \mathrm{~g}^{-1}$, pore volume of $0.72 \mathrm{~cm}^{3} \mathrm{~g}^{-1}$ and pore size of $31 \mathrm{~nm}$. 
An aqueous solution of $\mathrm{Pt}\left(\mathrm{NH}_{3}\right)_{2}\left(\mathrm{NO}_{2}\right)_{2}$ and $\mathrm{Co}\left(\mathrm{NO}_{3}\right)_{2} .6 \mathrm{H}_{2} \mathrm{O}$ or an acetone solution of $\mathrm{Ru}$ (acac) $)_{3}$ was used for the wetness impregnation of the support, in order to obtain 1 or $5 \%$ wt. of metal catalyst. After solvent evaporation, the solids were dried at $120{ }^{\circ} \mathrm{C}$ overnight, then calcined at $400{ }^{\circ} \mathrm{C}\left(\mathrm{Co}\right.$ and $\mathrm{Pt}$ ) and $350{ }^{\circ} \mathrm{C}(\mathrm{Ru})$, for $4 \mathrm{~h}$, under oxidative atmosphere (Ar: 48 $\left.\mathrm{mL} / \mathrm{min}-\mathrm{O}_{2}: 12 \mathrm{~mL} / \mathrm{min}\right)$. Finally, the solids were reduced by $\mathrm{H}_{2}(60 \mathrm{~mL} / \mathrm{min})$ at the same temperatures, for $4 \mathrm{~h}$. These calcination and reduction temperatures for the ruthenium catalyst were selected because $\mathrm{Ru}(\mathrm{acac})_{3}$ decomposes in air in one step, starting at $200{ }^{\circ} \mathrm{C}$ and completing at $350{ }^{\circ} \mathrm{C}$. Activation at temperature as high as $350{ }^{\circ} \mathrm{C}$ ensures complete removal of acetylacetonate ligands from the ruthenium precursor [22].

\subsection{Characterization of catalysts}

The chemical compositions of the samples were analyzed by inductively coupled plasmaatomic emission spectroscopy (ICP-AES), using an OPTIMA 2000 DV spectrometer. Diffractograms of the catalysts were obtained from XRD experiments, performed on a Siemens D5005 powder diffractometer using $\mathrm{Cu}-\mathrm{K} a$ radiation $(\lambda$ $=0.15186 \mathrm{~nm}$ ) and a back monochromator. XRD patterns were recorded using a dwell time of $2 \mathrm{~s}$, a step size of $0.04^{\circ}$ and a constant divergence slit equal to $1^{\circ}$. The crystalline planes were identified by comparison with PDF standards from ICDD. The $\mathrm{N}_{2}$ adsorptiondesorption measurements of $\mathrm{Al}_{2} \mathrm{O}_{3}$ were carried out at $-196{ }^{\circ} \mathrm{C}$, using a Micromeritics TriStar device. The surface area of the support was calculated using the Brunauer-Emmett-Teller method.

Electron microscopy studies of the catalysts were carried out on a JEOL 2000 FX instrument, operating at $200 \mathrm{kV}$. Catalyst specimens for electron microscopy were prepared by grinding the powder samples in an agate mortar, suspending and sonicating them in ethanol, and placing a drop of the suspension on a holey carbon copper grid. After evaporation of the solvent, the specimens were introduced into the microscope column. The diameter distribution of the particles was determined by counting a large number of particles $(>500)$ on the TEM micrographs and plotting $\mathrm{n}_{\mathrm{i}}$ as a function of $\mathrm{d}_{\mathrm{i}}$ $\left(n_{i}\right.$ is the number of particles within different intervals with given average diameters $d_{i}$ ). The mean surface diameter [23] of the particles is then given by Equation (1).

$$
d=\sum n_{i} d_{i}^{3} / \sum n_{i} d_{i}^{2}
$$

The measurements were done manually using the ImageJ program. The chemisorption measurements were carried out in a glass volumetric system. Catalyst samples of $\sim 0.2 \mathrm{~g}$ were placed into a reactor and reduced by pure $\mathrm{H}_{2}$, at $400{ }^{\circ} \mathrm{C}$, for 2 h. A 1/1 H/metal stoichiometry was assumed, in order to calculate the metallic dispersion from which the mean diameter $(d)$ of metal particles could be calculated using a cubic model, with one face in direct contact with the support (Equation (2)).

$$
d(n m)=\frac{5 \times 10^{5}}{\rho_{M} * S_{M} * D}
$$

where $\rho_{M}$ is the metal density, $S_{M}$ surface area occupied per metal atom, and $D$ the dispersion of the metal (Table 1) [24].

\subsection{Evaluation of the catalytic activity}

The catalytic oxidation of cyclohexane, with tertiobutylhydroperoxide (TBHP) as oxidant, was carried out in a glass round-bottom flask with a magnetic stirrer and a reflux condenser. First, commercial TBHP $70 \%$ in $\mathrm{H}_{2} \mathrm{O}$ (Aldrich) was stirred with cyclohexane in order to perform a phase transfer from water to cyclohexane. In a typical reaction, $60 \mathrm{mmol}(6.5 \mathrm{~mL})$ of cyclohexane and $60 \mathrm{mmol}(8.5 \mathrm{~mL})$ of oxidant (TBHP) are mixed in a closed Erlenmeyer flask and magnetically stirred for $24 \mathrm{~h}$. The organic phase was then separated from the aqueous phase. In order to control the phase transfer, the concentration of the remaining TBHP, in the aqueous phase, was determined by iodometric titration, and was found to be $<10 \%$. The solvent $(50 \mathrm{~mL})$ was then added to the TBHP-cyclohexane mixture. These reactants

Table 1. Physico-chemical properties of metals

\begin{tabular}{ccccc}
\hline Metal & $\begin{array}{c}\text { Molar mass } \\
\left(\mathrm{g} . \mathrm{mol}^{-1}\right)\end{array}$ & $\begin{array}{c}\text { Metal density } \\
\left({\left.\mathrm{g} . \mathrm{cm}^{-3}\right)}^{-1}\right.\end{array}$ & $\begin{array}{c}\text { Surface of atom } \\
\left(\AA^{2}\right)\end{array}$ & $\begin{array}{c}\mathrm{D} \times \mathrm{d} \\
(\mathrm{nm})\end{array}$ \\
\hline $\mathrm{Ru}$ & 101.07 & 12.30 & 6.35 & 107.4 \\
$\mathrm{Pt}$ & 195.08 & 21.45 & 8.08 & 93.6 \\
$\mathrm{Co}$ & 58.93 & 8.90 & 5.43 & 101.22 \\
\hline
\end{tabular}


and the solvent were introduced in a glass round-bottom flask and heated to $70{ }^{\circ} \mathrm{C}$ under vigorous stirring. The catalyst $(0.05 \mathrm{~g})$ was subsequently added to the reaction mixture (time zero). The reaction products were identified by comparison with authentic products and the course of reactions was followed by gas chromatography (GC), using a Varian CP-3800 gas chromatograph equipped with a CP-WAX 52 $\mathrm{CB}$ column. A flame ionization detector (FID) was used and a quantity of $0.5 \mu \mathrm{L}$ from the sample was analyzed. Before GC analysis, the remaining TBHP was decomposed by introducing an excess of triphenylphosphine. On the other hand, to control this remaining TBHP, an iodometric titration was performed at the end of the reaction (after $6 \mathrm{~h}$ ) by testing the organic phase. The catalytic performances were reported in terms of cyclohexane conversion and selectivity towards products. They are calculated following the expressions in Equations (3$4)$ :

Conversion $(\%)=100 x \frac{\left[C_{6} H_{12}\right]_{0}-\left[C_{6} H_{12}\right]_{e}}{\left[C_{6} H_{12}\right]_{0}}$

Selectivity $(\%)=100 x \frac{\text { moles of individualproduct }}{\text { moles of total product }}$

\section{Results and Discussion}

\subsection{Characterization}

As measured by ICP-OES, the metal content in all catalysts is either 1 or $5 \%$ (Table 2). Figure 1 shows the XRD patterns of the bare $\mathrm{Al}_{2} \mathrm{O}_{3}$ support and the different catalysts. The alumina support shows two crystalline phases with sharper peaks, indicating that alumina is in $\delta$ and $\gamma$ forms. The diffractogram of $\mathrm{Ru} / \mathrm{Al}_{2} \mathrm{O}_{3}$ confirms that metallic ruthenium is present in catalysts as a result of the reduction operation, and no $\mathrm{RuO}_{2}$ peak is observed. The $\mathrm{Ru}$ diffraction peaks $\left(38.4^{\circ}, 42.2^{\circ}, 44.0^{\circ}, 58.3^{\circ}\right.$, and $69.4^{\circ}$ $2 \theta$, JCPDS no. 6-663) are sufficient for an estimation of the average ruthenium crystallite size, which is $9 \mathrm{~nm}$, with a relative standard deviation of $10 \%$. Diffraction peaks at $39.76^{\circ}$, $46.24^{\circ}$ and $67.45^{\circ} 2 \theta$ (JCPDS no. $4-802$ ), characteristic of metallic $\mathrm{Pt}$, were detected on the diffraction patterns of $\mathrm{Pt} / \mathrm{Al}_{2} \mathrm{O}_{3}$. No platinum oxide was observed. Crystalline $\mathrm{Co}_{3} \mathrm{O}_{4}$ and $\mathrm{CoO}$ phases were observed in $\mathrm{Co} / \mathrm{Al}_{2} \mathrm{O}_{3}$. No peaks of metallic Co were detected. The peaks at $19.08^{\circ}$, $31.38^{\circ}, 36.88^{\circ}, 44.88^{\circ}, 59.38^{\circ}$ and $65.28^{\circ} 2 \theta$ were attributed to the cubic phase of $\mathrm{Co}_{3} \mathrm{O}_{4}$ with Fd3m space group (JCPDS no. 42-1467). In addition, the lines at $42.4^{\circ}$ and $34.5^{\circ} 2 \theta$ could be assigned to the cubic structures of CoO (JCPDS no. 71-1178).

The metal dispersion of catalysts was obtained by $\mathrm{H}_{2}$ chemisorption. The percentage of metallic dispersion was calculated, assuming an H/M atomic ratio equal to 1 [25,26], as shown in Table 2 . The $1 \% \mathrm{Ru}$ or Pt catalysts gave a dispersion $(20 \%)$ lower than that obtained with the $5 \%$ catalysts. Ruthenium catalysts showed higher dispersion than platinum ones. DRX results of cobalt catalysts showed the formation of cobalt oxides and chemisorption measurements were not possible.

TEM analysis (micrographs and histograms) for $\mathrm{Ru} / \mathrm{Al}_{2} \mathrm{O}_{3}, \mathrm{Pt} / \mathrm{Al}_{2} \mathrm{O}_{3}$ and $\mathrm{Co} / \mathrm{Al}_{2} \mathrm{O}_{3}$

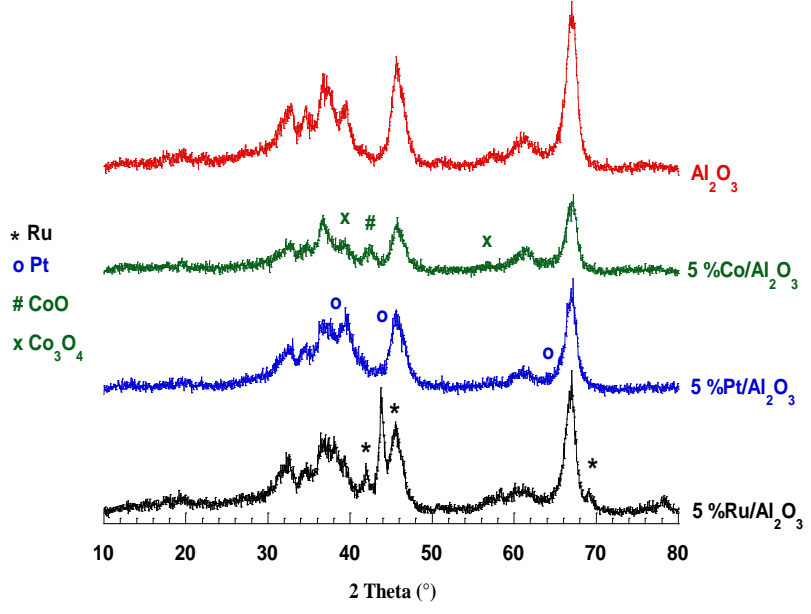

Figure 1. X-ray diffraction (XRD) patterns of catalysts

Table 2. Metallic accessibility and crystallite size for various catalysts

\begin{tabular}{ccccccc}
\hline \multirow{2}{*}{ Catalyst } & ICP (wt.\%) & \multicolumn{2}{c}{ Chemisorption } & & \multicolumn{2}{c}{ TEM } \\
\cline { 3 - 4 } \cline { 6 - 7 } & & $\begin{array}{c}\text { Dispersion } \\
(\%)\end{array}$ & $\begin{array}{c}\text { Particle size } \\
(\text { nm) }\end{array}$ & & $\begin{array}{c}\text { Dispersion } \\
(\%)\end{array}$ & $\begin{array}{c}\text { Particle size }^{\mathrm{b}} \\
(\mathrm{nm})\end{array}$ \\
\hline $\mathrm{Ru} / \mathrm{Al}_{2} \mathrm{O}_{3}$ & 1.02 & 20 & 5.3 & & 18 & 5.8 \\
& 5.09 & 45 & 2.4 & & 42 & 2.5 \\
$\mathrm{Pt} / \mathrm{Al}_{2} \mathrm{O}_{3}$ & 1.02 & 20 & 4.7 & & 23 & 4.0 \\
& 5.06 & 28 & 3.3 & & 29 & 3.2 \\
$\mathrm{Co} / \mathrm{Al}_{2} \mathrm{O}_{3}$ & 1.07 & $/$ & $/$ & & $/$ & $/$ \\
& 5.08 & $/$ & $/$ & & $/$ & $/$ \\
\hline
\end{tabular}


systems are shown in Figures 2, 3, and 4, respectively. The $5 \% \mathrm{Pt} / \mathrm{Al}_{2} \mathrm{O}_{3}$ and $5 \% \mathrm{Ru} / \mathrm{Al}_{2} \mathrm{O}_{3}$ catalyst samples were well dispersed with no indication of agglomeration of the metal particles. All of these materials have a spherical morphology. The ruthenium system showed nanoparticle sizes ranging from 1.7 to $4.6 \mathrm{~nm}$ with a mean size of $2.5 \mathrm{~nm}$ (Figure 2).

In the platinum system, the size distribution ranges between 1.8 and $6 \mathrm{~nm}$, with a mean particle size of $3.2 \mathrm{~nm}$ (Figure 3). TEM analysis of $\mathrm{Co} / \mathrm{Al}_{2} \mathrm{O}_{3}$ (Figure 4) revealed an intensive agglomeration of cobalt particles on these samples and, then, a true reliable distribution could not be given. The average size of these agglomerations was between 8 and $10 \mathrm{~nm}$. Zhou et al. [5] showed that $\mathrm{Co}_{3} \mathrm{O}_{4}$ oxide has a

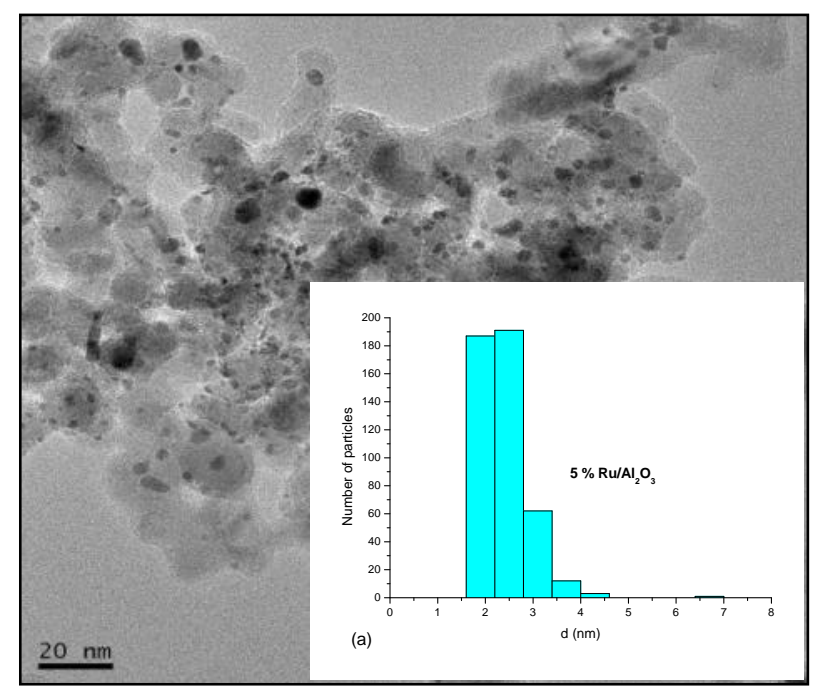

Figure 2. Micrography and histogram for 5 $\% \mathrm{Ru} / \mathrm{Al}_{2} \mathrm{O}_{3}$

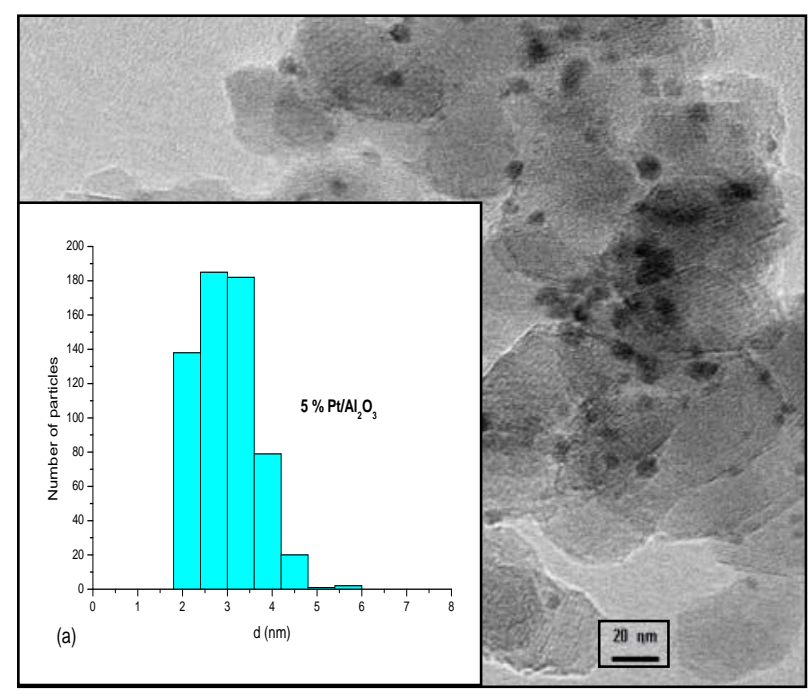

Figure 3. Micrography and histogram of $5 \%$ $\mathrm{Pt} / \mathrm{Al}_{2} \mathrm{O}_{3}$ platelet morphology forming, in most cases, quite large agglomerations. As shown, a very good correspondence between the mean particle sizes estimated from $\mathrm{H}_{2}$ chemisorption and TEM was obtained for all catalyst samples $(\mathrm{Ru}$ and Pt) (Table 2).

\subsection{Catalytic oxidation of cyclohexane}

The activities of the catalysts for the catalytic oxidation of cyclohexane with TBHP at 70 ${ }^{\circ} \mathrm{C}$, in acetic acid or acetonitrile, are presented in Table 3. The desired products are cyclohexanol $\left(\mathrm{C}_{6} \mathrm{H}_{11} \mathrm{OH}\right)$ and cyclohexanone $\left(\mathrm{C}_{6} \mathrm{H}_{10} \mathrm{O}\right)$, but other products like cyclohexyl hydroperoxide, adipic acid, ester dicyclohexyl adipate, hexanolactone, and other esters [5], among which is cyclohexyl acetate [27], did also form. In general, cyclohexyl hydroperoxide can be decomposed to cyclohexanol and cyclohexanone in presence of $\mathrm{PPh}_{3}$ (triphenylphosphine) introduced before GC analysis, thus increasing the yield of the target compounds.

The present study focused on the selectivity towards olone only (cyclohexanol and cyclohexanone). The amount of catalyst used was $0.05 \mathrm{~g}$ and the cyclohexane to TBHP mole ratio was (1:1). A blank oxidation reaction (i.e. without catalyst) was carried out under typical reaction conditions and no oxidation product was formed. Moreover, to check the impact of the support on the cyclohexane oxidation reaction, $\mathrm{Al}_{2} \mathrm{O}_{3}$ was tested for its catalytic properties in the presence of acetic acid as solvent. The support exhibited a conversion less than $15 \%$ with selectivity around $10.3 \mathrm{mmol}$ (17.2\%) (Olone). As expected, these results are found to be close to those of Bellifa et al. [28] and Zhao et al.

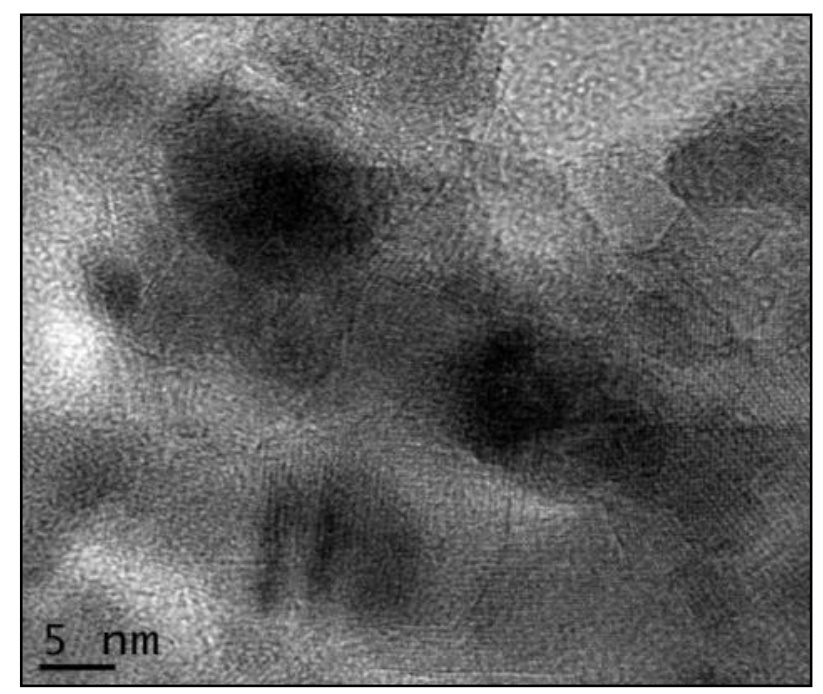

Figure 4. Micrography of $5 \% \mathrm{Co} / \mathrm{Al}_{2} \mathrm{O}_{3}$ 
[29]. Table 3 details the catalytic activities of alumina-supported ruthenium in the presence of acetic acid and acetonitrile. Cyclohexanol and cyclohexanone selectivities increase with metal content [17]. The $1 \%$ catalysts showed a modest selectivity increase compared to $5 \%$ ones. So, one can assume that the support participates in the reaction via a functional mechanism (support and metal), as reported by Wangcheng et al. [30].

In the presence of TBHP and acetic acid as solvent, turnover frequencies (TOF) of $1863 \mathrm{~h}^{-1}$ and $288 \mathrm{~h}^{-1}$ were obtained, after $6 \mathrm{~h}$ of catalytic oxidation, for $1 \%$ and $5 \% \mathrm{Ru} / \mathrm{Al}_{2} \mathrm{O}_{3}$ systems, respectively. The TOF values obtained are comparable (1907 $\mathrm{h}^{-1}$ for $\left.1.21 \% \mathrm{Au} / \mathrm{MCM}-41\right)$ [31] to or higher $\left(184 \mathrm{~h}^{-1}\right)$ [32] than those of $\mathrm{CoFe}_{2} \mathrm{O}_{4}$ catalysts reported in the literature; however they are smaller than the highest value which amounts to $11900 \mathrm{~h}^{-1}$ for $\mathrm{Au} / \mathrm{HAP}$ (Hydroxyapatite) [33], and $2592 \mathrm{~h}^{-1}$ for $1 \%$ $\mathrm{Au} / \mathrm{Al}_{2} \mathrm{O}_{3}$. Nevertheless, gold-based catalysts are regarded as expensive catalysts compared to ruthenium based catalyst which is the least expensive among the noble metals. This represents a cyclohexane conversion of $35.6 \%$, whereas the selectivity towards the formation of cyclohexanol is $10.0 \mathrm{mmol}(16.7 \%)$ and towards cyclohexanone $12.4 \mathrm{mmol}$ (20.7 \%). By comparing the two solvents, the activities obtained under acidic conditions were found to be higher compared to those obtained in acetonitrile. These activities decreased when the ruthenium content increased. This observation suggests that the acetic acid was oxidized by TBHP to form peracetic acid in situ, which served as a better oxidant $[34,36]$. The amount of ruthenium leached, of our nanostructured material, is determined after reaction and found $<50 \mathrm{ppm}$.
Platinum catalysts (Table 3), in acetic acid and after $6 \mathrm{~h}$, showed high activity towards cyclohexane oxidation, and gave turnovers of $2830 \mathrm{~h}^{-1}$ and $782 \mathrm{~h}^{-1}$, for $1 \%$ and $5 \% \mathrm{Pt} / \mathrm{Al}_{2} \mathrm{O}_{3}$, respectively. These correspond to conversions $14.8 \%$ and $28.4 \%$, respectively. In the presence of acetonitrile, it is clear that platinum does not promote the formation of cyclohexanone. The cyclohexanol selectivity decreases when the platinum content increases from 1 to $5 \%$ [30]. As can be seen from the comparison data, the ruthenium-based catalyst is more active towards oxidation products than the platinum-based catalyst.

After the reaction, the ICP analysis of platinum-based catalyst did not exhibit leaching, which means that it is a heterogeneous catalytic system. For cobalt nanoparticles supported on alumina, the results reveal that these solids are capable of oxidizing the substrate used in this study. After $6 \mathrm{~h}$ of reaction time, and in the presence of acetic acid as solvent, the turnovers were found equal to $177 \mathrm{~h}^{-1}$ and $49 \mathrm{~h}^{-1}$, which correspond to $14.8 \%$ and $20.7 \%$ conversions to cyclohexane, for $1 \%$ and $5 \% \mathrm{Co}_{\mathrm{x}} \mathrm{O}_{\mathrm{y}} / \mathrm{Al}_{2} \mathrm{O}_{3}$, respectively (Table 3). These results show that cobalt-based catalysts are less active than their ruthenium and platinum counterparts, in the conditions under consideration. It can be seen from Table 3 that a relatively lower conversion was obtained in the case of acetonitrile. The chemical analysis of the catalyst, after reaction, revealed that $20 \%$ of cobalt, which was in the catalyst, passed into the solution. Therefore, it is not possible to check whether the catalysis took place in the heterogeneous system $\mathrm{Co}_{\mathrm{x}} \mathrm{O}_{\mathrm{y}} / \mathrm{Al}_{2} \mathrm{O}_{3}$, in a mixture of heterogeneous and homogeneous catalysts, or just as a homogeneous system.

Table 3. Oxidation of cyclohexane with $\mathrm{M} / \mathrm{Al}_{2} \mathrm{O}_{3}$ catalysts

\begin{tabular}{|c|c|c|c|c|c|c|c|c|c|}
\hline \multirow{3}{*}{ Catalyst } & \multirow{3}{*}{$\begin{array}{l}\text { wt. } \\
(\%)\end{array}$} & \multicolumn{4}{|c|}{ Acetic acid } & \multicolumn{4}{|c|}{ Acetonitrile } \\
\hline & & \multicolumn{2}{|c|}{ Products (\%) } & \multirow{2}{*}{$\begin{array}{r}\text { TOF } \\
\left(\mathrm{h}^{-1}\right)\end{array}$} & \multirow{2}{*}{$\begin{array}{c}\text { Conv }^{b} \\
(\%)\end{array}$} & \multicolumn{2}{|c|}{ Products (\%) } & \multirow{2}{*}{$\begin{array}{r}\text { TOF } \\
\left(\mathrm{h}^{-1}\right)\end{array}$} & \multirow{2}{*}{$\begin{array}{c}\text { Conv }^{b} \\
(\%)\end{array}$} \\
\hline & & Alcohol & Ketone & & & Alcohol & Ketone & & \\
\hline $\mathrm{Al}_{2} \mathrm{O}_{3}$ & 1 & 12.2 & 5.0 & $2.9^{a}$ & 14 & 0.0 & 0.0 & 0 & 0 \\
\hline \multirow[t]{2}{*}{$\mathrm{Ru} / \mathrm{Al}_{2} \mathrm{O}_{3}$} & 1.02 & 7.2 & 18.4 & 1863 & 18.8 & 34.2 & 26.3 & 624 & 6.3 \\
\hline & 5.09 & 16.7 & 20.7 & 288 & 35.6 & 17.2 & 20.3 & 238 & 29.4 \\
\hline \multirow[t]{2}{*}{$\mathrm{Pt} / \mathrm{Al}_{2} \mathrm{O}_{3}$} & 1.02 & 22.5 & 6.4 & 2830 & 14.8 & 35.0 & 0.0 & 1377 & 7.2 \\
\hline & 5.06 & 16.7 & 4.2 & 782 & 28.4 & 5.0 & 0.0 & 481 & 17.5 \\
\hline \multirow[t]{2}{*}{$\mathrm{Co} / \mathrm{Al}_{2} \mathrm{O}_{3}$} & 1.07 & 11.2 & 5.7 & $177.4^{\mathrm{a}}$ & 14.8 & 7.0 & 4.2 & $145^{\mathrm{a}}$ & 12.3 \\
\hline & 5.08 & 23.4 & 6.7 & $48.8^{\mathrm{a}}$ & 20.7 & 5.0 & 3.7 & $65.6^{\mathrm{a}}$ & 27.8 \\
\hline
\end{tabular}

$\mathrm{C}_{6} \mathrm{H}_{12}=6.5 \mathrm{~mL} ; \mathrm{TBHP}=8.5 \mathrm{~mL} ;$ solvent $=50 \mathrm{~mL} ;$ catalyst $=0.05 \mathrm{~g} ; \mathrm{t}=6 \mathrm{~h} ; \mathrm{T}=70^{\circ} \mathrm{C}$;

TOF $=$ mole of converted cyclohexane per unit time per mole of dispersed ruthenium or platinum.

a TOF : mole of converted cyclohexane per unit time per mole of cobalt or $\mathrm{Al}_{2} \mathrm{O}_{3}$.

${ }^{\mathrm{b}}$ After $6 \mathrm{~h}$ of reaction time 
In summary, one can say that concerning the catalytic activity and selectivity of aluminasupported ruthenium, platinum and cobalt nanoparticle towards the oxidation reaction of cyclohexane, it can be proven that noble and non-noble metals can be active for the oxidation of cyclohexane. The support is active during the cyclohexane oxidation, but the presence of the metal clearly improves the reaction activity which increases with the metal loading. From the literature, it is well established that some transition metal ions can be catalytically activated towards the oxidation reactions of certain organic substrates when $\mathrm{H}_{2} \mathrm{O}_{2}$ or $\mathrm{RO}_{2} \mathrm{H}$ are used as oxidizing agents.

These reactions can be classified in two categories, depending on whether the active species in the oxidation reaction is (i) peroxometal or (ii) oxometal [37]. Generally, the last transition metals employ an oxometal intermediate. Some other elements, such as vanadium, can use either route, depending on the substrate. Most transition metals that catalyze oxygen-transfer processes, whether via peroxometal or oxometal, are also able to catalyze processes via free radicals formed from peroxide compounds $[38,40]$.

Thus, as expected in the cyclohexane oxidation reaction, and in the presence of the two solvents, the activity increases as $\mathrm{Ru} / \mathrm{Al}_{2} \mathrm{O}_{3}$ > $\mathrm{Pt} / \mathrm{Al}_{2} \mathrm{O}_{3}>\mathrm{Co} / \mathrm{Al}_{2} \mathrm{O}_{3}$. The acetic acid when used as solvent is better than acetonitrile, as it allows higher conversion and selectivity towards cyclohexanol and cyclohexanone. From the leaching results, it is possible to state that the systems studied have the following order of stability: $\mathrm{Pt} / \mathrm{Al}_{2} \mathrm{O}_{3}>\mathrm{Ru} / \mathrm{Al}_{2} \mathrm{O}_{3}>\mathrm{Co}_{\mathrm{x}} \mathrm{O}_{\mathrm{y}} / \mathrm{Al}_{2} \mathrm{O}_{3}$.

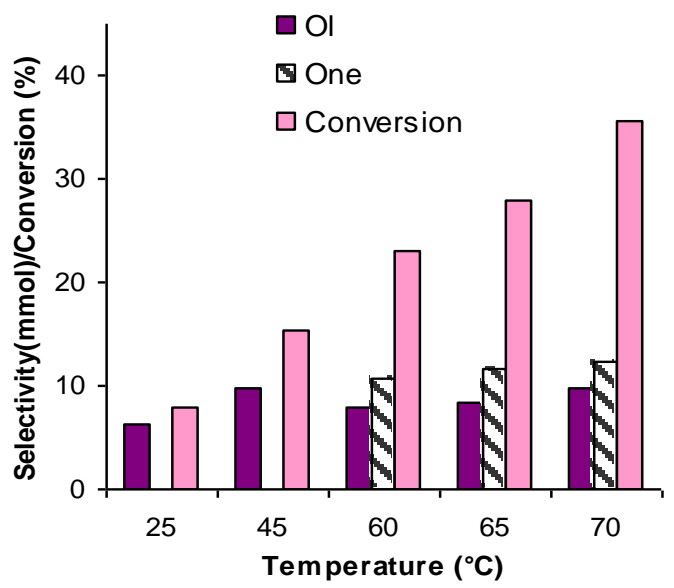

Figure 5. Effects of reaction temperature on conversion and selectivity over $5 \% \mathrm{Ru} / \mathrm{Al}_{2} \mathrm{O}_{3}$; $\mathrm{C}_{6} \mathrm{H}_{12}=6.5 \mathrm{~mL}$, TBHP $=8.5 \mathrm{~mL}$, acetic acid $=$ $50 \mathrm{~mL}$, catalyst $=0.05 \mathrm{~g}, \mathrm{t}=6 \mathrm{~h}$

\subsubsection{Optimization of reaction conditions}

Due to the good performance of the catalyst $\mathrm{Ru} / \mathrm{Al}_{2} \mathrm{O}_{3}$, this study focused, in the following section, on the influence of various parameters on cyclohexane conversion and selectivity towards cyclohexanone and cyclohexanol over 5 $\% \mathrm{Ru} / \mathrm{Al}_{2} \mathrm{O}_{3}$. The reaction conditions were optimized in acetic acid. The reactions were conducted at the temperatures $25,45,60,65$, and $70{ }^{\circ} \mathrm{C}$, as shown in Figure 5 .

As expected, the cyclohexane conversion increases as a function of the temperature. The distribution of cyclohexanol and cyclohexanone shows no formation of cyclohexanone at 25 and $45^{\circ} \mathrm{C}$, and a temperature increase clearly favors the production of cyclohexanone. A similar behavior was noted by Zhou et al. [5], and Yuan et al. [41]. These results show that when the temperature increased from 25 to $70{ }^{\circ} \mathrm{C}$, the conversion and selectivity towards cyclohexanone and cyclohexanol increased and
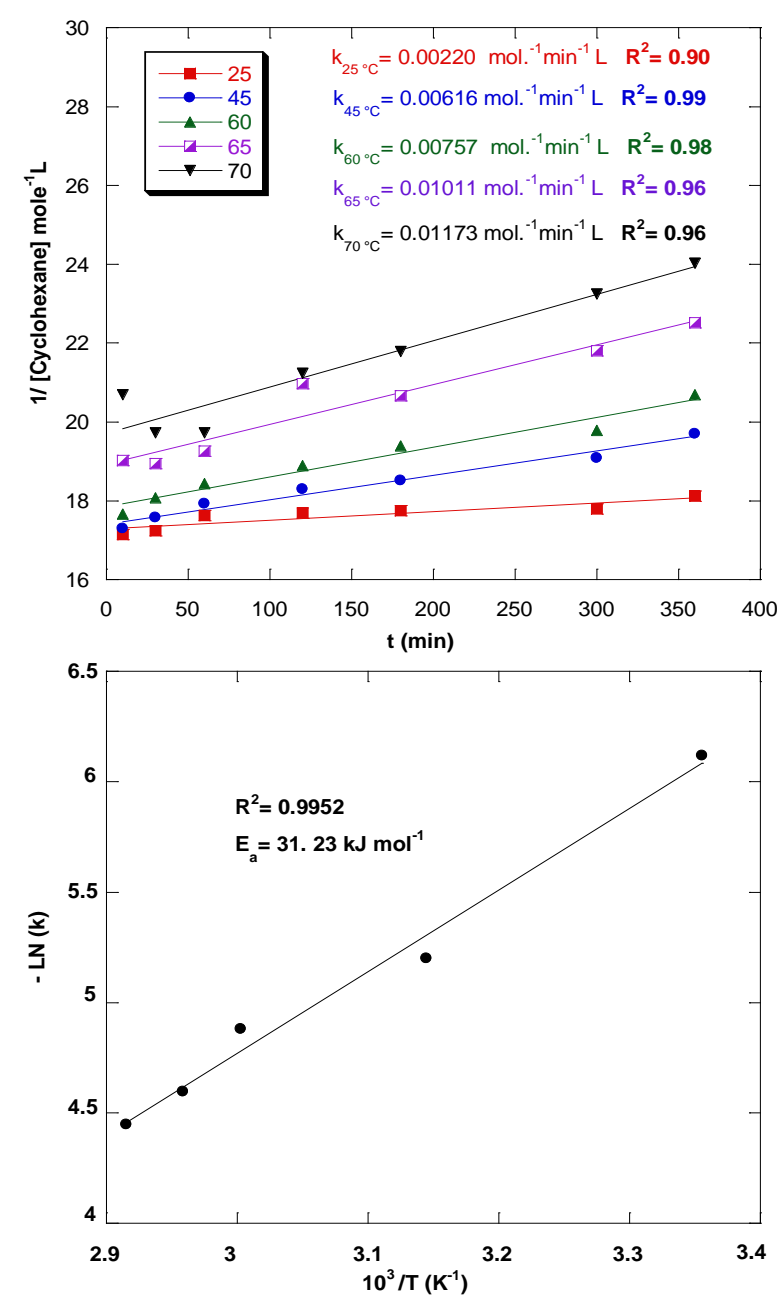

Figure 6. Kinetic data at different temperatures and Arrhenius plot for the oxidation of cyclohexane 
reached their maxima. To test the order of the reaction, both $\ln [A] /[A]_{\mathrm{o}}$ and $1 /[A]$ were plotted against $t$ for the reactions.

The second order plots gave a straight line, indicating that the reaction is of the $2^{\text {nd }}$ order, as shown in Figure 6. The activation energy, calculated from the slope of the straight line (Figure 6), is $31.23 \mathrm{~kJ} \mathrm{~mol}^{-1}$, which is lower than the values reported in several previous works [42-47]. The effect of the mole ratio was examined by varying the cyclohexane/TBHP mole ratios (1:1 and 1:2), with $0.05 \mathrm{~g}$ of $\mathrm{Ru} / \mathrm{Al}_{2} \mathrm{O}_{3}$ catalyst at $70{ }^{\circ} \mathrm{C}$, for $6 \mathrm{~h}$ (Figure 7). An increase in the TBHP concentration (1:2) resulted in an increase in the selectivity of the oxidized products, such as: cyclohexanol (from $\sim 10 \mathrm{mmol}(16.7 \%)$ to $20 \mathrm{mmol}(33.4 \%)$ ) and cyclohexanone (from $12.4 \mathrm{mmol}(20.7 \%)$ to 37 mmol (61.7 \%)); however, the conversion remained constant (35.6\%). This might be explained by the fact that the TBHP used may have increased the conversion of cyclohexanol, which in turn reacted with the acetic acid in excess, which led to an increase in cyclohexanone formation.

A similar behavior was noted on TS-1 [48]. On the other hand, TBHP gave cyclohexanone as the major product, owing to its much stronger oxidizing capability. The same observation was reported by Selvam et al. [49] and Kumar et al. [27]. According to them, the increase in the cyclohexanone selectivity, with the increase in TBHP, is due to the oxidation of cyclohexanol to cyclohexanone in the presence of excess amount of TBHP.

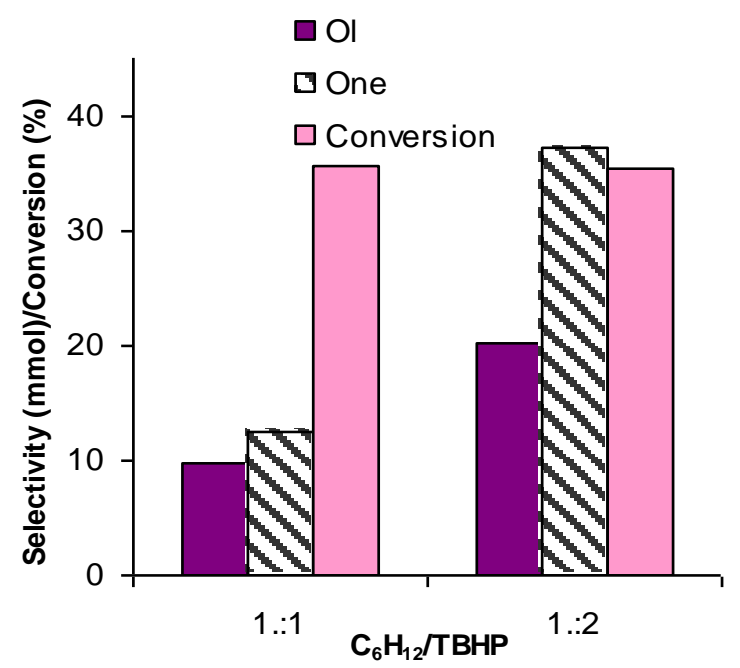

Figure 7. Effects of $\mathrm{C}_{6} \mathrm{H}_{12} / \mathrm{TBHP}$ mole ratio on conversion and selectivity over $5 \% \mathrm{Ru} /$ $\mathrm{Al}_{2} \mathrm{O}_{3} ;$ Acetic acid $=50 \mathrm{~mL}$; catalyst $=0.05$ $\mathrm{g} ; \mathrm{t}=6 \mathrm{~h} ; \mathrm{T}=70^{\circ} \mathrm{C}$
The effects of the amount of catalyst on the reaction were also studied. The results are presented in Figure 8. One can see that the olone selectivity increased from $22 \mathrm{mmol}(\sim 37 \%)$ to $57.6 \mathrm{mmol}$ (96\%), while the conversion decreased from $35.6 \%$ to $25 \%$, as the mass of catalyst rose from $0.05 \mathrm{~g}$ to $0.1 \mathrm{~g}$. These results coincide with those of Lu et al. [21]. The presence of a high number of active centers eventually causes an increase in the rate of reaction, thereby increasing the olone selectivity. On the other hand, these results indicate that in the system catalyzed by $\mathrm{Ru} / \mathrm{Al}_{2} \mathrm{O}_{3}$, only a small amount of catalyst was active in the oxidation of cyclohexane [22]. This could also be attributed to the competition of interactions between the metal-oxo species in the catalyst and the hydroperoxy species and cyclohexane [50, 51]. It can therefore be concluded that the amount of $0.1 \mathrm{~g}$ of catalyst is optimal for this catalytic system.

The effect of ruthenium loading on the oxidation of cyclohexane was also examined. The cyclohexane conversion, as well as the (cyclohexanone + cyclohexanol) selectivity over different Ru-loaded catalysts, is shown in Figure 9. However, as the ruthenium loadings of our samples increased from 0 to $5.0 \%$, the cyclohexane conversion and the total selectivity of the oxygenated products increased, while the TOF value decreased. This behavior is closely related to the size of $\mathrm{Ru}$ particles. The catalyst $5 \% \mathrm{Ru} / \mathrm{Al}_{2} \mathrm{O}_{3}$ exhibited the smallest and most uniform $\mathrm{Ru}$ particles (with an average size of about $2.5 \mathrm{~nm}$ ), followed by catalysts $3.7 \%$ $\mathrm{Ru} / \mathrm{Al}_{2} \mathrm{O}_{3}$ (about $4.4 \mathrm{~nm}$ in size) and $1 \%$

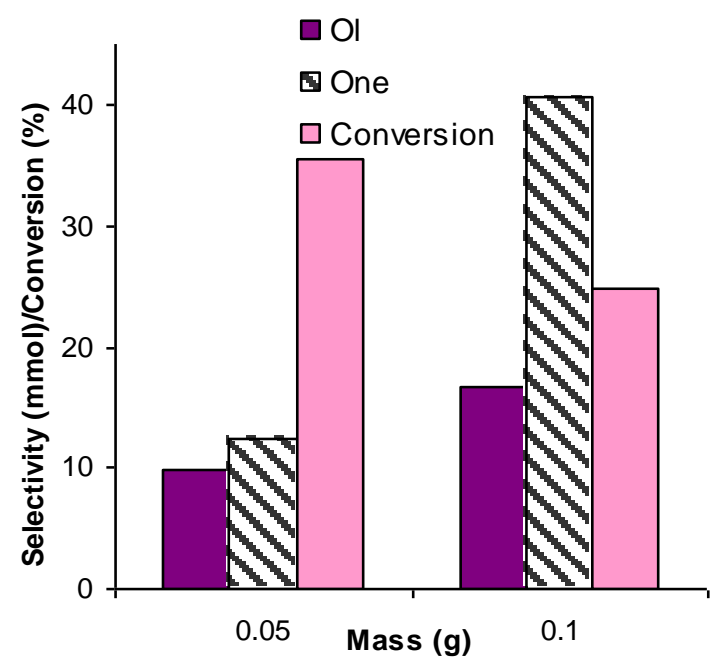

Figure 8. Effects of the amount of catalyst on conversion and selectivity over $5 \% \mathrm{Ru} / \mathrm{Al}_{2} \mathrm{O}_{3}$; $\mathrm{C}_{6} \mathrm{H}_{12}=6.5 \mathrm{~mL} ; \mathrm{TBHP}=8.5 \mathrm{~mL}$; Acetic acid $=$ $50 \mathrm{~mL} ; \mathrm{T}=70{ }^{\circ} \mathrm{C} ; \mathrm{t}=6 \mathrm{~h}$ 
$\mathrm{Ru} / \mathrm{Al}_{2} \mathrm{O}_{3}$ (around $5.8 \mathrm{~nm}$ ). The high activity of the catalyst, which contains small size Ru particles, may be explained as follows. This result was expected, because small particles have a higher density, which gives a more active surface of $\mathrm{Ru}$ atoms. This is favorable for the adsorption and activation of the oxidant during the oxidation reaction, resulting in a higher catalytic activity [50,52]. It is therefore clear that the catalytic activity depends on the $\mathrm{Ru}$ particle size. Another reason for the low catalytic activity, with low ruthenium concentrations, may be due to partial incorporation of $\mathrm{Ru}$ into the bulk support [53].

In addition, in order to check the catalyst recyclability, five reaction runs were carried out under typical reaction conditions, using acetic acid as solvent. The results are shown in Figure 10. After each reaction, the catalyst was separated by filtration, and then reused under the same reaction conditions. After deactivation, it was dried at $350{ }^{\circ} \mathrm{C}$, for $2 \mathrm{~h}$, under argon. The regenerated catalyst was examined under the same conditions.

It can be seen that the olone selectivity decreases with the number of reaction runs, and after the fifth run the catalyst is completely deactivated. The selectivity towards cyclohexanol and cyclohexanone on a recycled catalyst was slightly lower than that obtained on a fresh one. The deactivation of the catalyst is likely related to common inhibition processes found in oxidation reactions, such as the adsorption of the oxygenated product species on the catalyst surfaces [54]. These results disclose the fact that the catalyst is stable or could be recycled after the reaction.

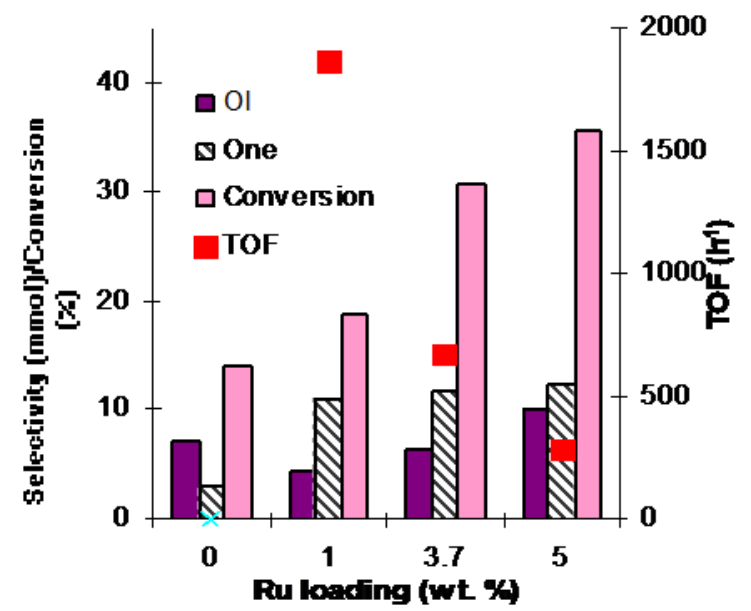

Figure 9. Effect of Ru loading on conversion and selectivity over $\mathrm{x} \% \mathrm{Ru} / \mathrm{Al}_{2} \mathrm{O}_{3}$; Acetic acid = $50 \mathrm{~mL}$; Catalyst $=0.05 \mathrm{~g} ; \mathrm{t}=6 \mathrm{~h} ; \mathrm{T}=70^{\circ} \mathrm{C}$

\section{Conclusions}

Various metal-supported alumina catalysts were prepared by the incipient wetness impregnation method. The characterization of the catalysts obtained, confirmed that ruthenium and platinum are in metallic form while cobalt is in the form of oxides $\mathrm{Co}_{3} \mathrm{O}_{4}$ and $\mathrm{CoO}$. The liquid-phase oxidation of cyclohexane was performed using tertbutyl hydroperoxide (TBHP) at $70{ }^{\circ} \mathrm{C}$. The support $\mathrm{Al}_{2} \mathrm{O}_{3}$ was active during the oxidation of cyclohexane but the presence of a metal clearly improved the activity of the reaction. All the prepared catalysts showed higher catalytic activity and stability for the oxidation of cyclohexane in acetic acid, compared to acetonitrile. All the prepared catalysts exhibited high catalytic activities and could reach a cyclohexane conversion of $35.6 \%$ and selectivity of $57.6 \mathrm{mmol}$ towards the desired products (olone).

Several reaction parameters in the cyclohexane oxidation reaction over $5 \% \mathrm{Ru} / \mathrm{Al}_{2} \mathrm{O}_{3}$, i.e. the temperature, amount of catalyst and concentration of TBHP in terms of the cyclohexane/TBHP ratio, were optimized to achieve maximum selectivity to cyclohexanol and cyclohexanone. After optimization of these parameters, the best reaction conditions were obtained for $0.1 \mathrm{~g}$ of catalyst, $\mathrm{T}=70{ }^{\circ} \mathrm{C}, \mathrm{C}_{6} \mathrm{H}_{12} / \mathrm{TBHP}$ molar ratio $=1: 2$ and $t=6 \mathrm{~h}$. The catalyst was recycled and reused five times. It exhibited practically the same activity and selectivity as those of fresh catalyst after heat treatment, under argon.

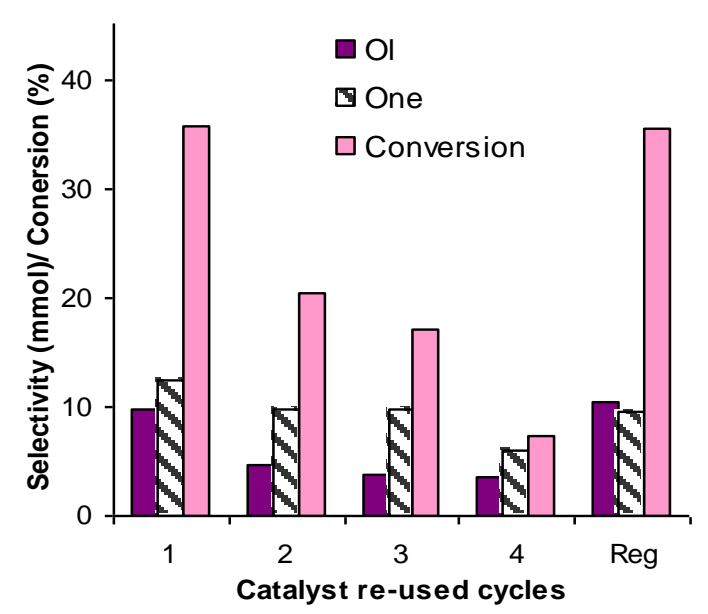

Figure 10. Catalyst recycling for cyclohexane oxidation over $5 \% \mathrm{Ru} / \mathrm{Al}_{2} \mathrm{O}_{3} ; \mathrm{C}_{6} \mathrm{H}_{12}=6.5 \mathrm{~mL}$; TBHP $=8.5 \mathrm{~mL}$; acetic acid $=50 \mathrm{~mL}$; catalyst $=$ $0.05 \mathrm{~g} ; \mathrm{t}=6 \mathrm{~h} ; \mathrm{T}=70{ }^{\circ} \mathrm{C}$ 


\section{Acknowledgement}

The authors would like to thank the Algerian Ministry of Higher Education and Scientific Research for the fellowship funding at the University of Poitiers, France. They also thank Pr C. Kappenstein and Pr L. Pirault-Roy from IC2MP (University of Poitiers, France) for their precious help.

\section{References}

[1] Sheldon, R.A. (1981) Metal-catalyzed Epoxidation of Olefins with Hydroperoxides, in Aspects of Homogeneous Catalysis, R. Ugo (Ed.); Reidel, Dordrecht, Volume 4, pp. 3-70.

[2] Hao, J., Liu, B., Cheng, H., Wang, Wang, Q.J., Cai, S., Zhao, F. (2009). Cyclohexane Oxidation on A Novel $\mathrm{Ti}_{70} \mathrm{Zr}_{10} \mathrm{Co}_{20}$ Catalyst Containing Quasicrystal. Chemical Communications, 23: 3460-3462.

[3] Sato, K., Aoki, M., Noyori, R. (1998). A "Green" Route to Adipic Acid: Direct Oxidation of Cyclohexenes with 30 Percent Hydrogen Peroxide. Science, 281: 1646-1647.

[4] Cavani, F., Centi, G., Perathoner, S., Trifiro, F. (2009). Sustainable Industrial Processes, WILEY-VCH Verlag GmbH \& Co, KGaA, Weinheim.

[5] Zhou, L., Xu, J., Miao, H., Wang, F., Li, X. (2005). Catalytic Oxidation of Cyclohexane to Cyclohexanol and Cyclohexanone over $\mathrm{Co}_{3} \mathrm{O}_{4}$ Nanocrystals with Molecular Oxygen. Applied Catalysis A: General, 292: 223-228.

[6] Chen, C., Xu, J., Zhang, Q., Ma, H., Miao, H., Zhou, L. (2009). Direct Synthesis of Bifunctionalized Hexagonal Mesoporous Silicas and Its Catalytic Performance for Aerobic Oxidation of Cyclohexane. The Journal of Physical Chemistry C, 113: 2855-2860.

[7] Deng, Y., Ma, Z., Wang, K., Chen, J. (1999). Clean Synthesis of Adipic Acid by Direct Oxidation of Cyclohexene with $\mathrm{H}_{2} \mathrm{O}_{2}$ over Peroxytungstate-Organic Complex Catalysts. Green Chemistry, 1: 275-276.

[8] Thomas, J.M., Raja, R. (2006). Innovations in Oxidation Catalysis Leading to A Sustainable Society. Catalysis Today, 117: 22-31.

[9] Guo, C.C., Chu, M.F., Liu, Q., Liu, Y., Guo, D.C., Liu, X.Q. (2003). Effective Catalysis of Simple Metalloporphyrins for Cyclohexane Oxidation with Air in the Absence of Additives and Solvents. Applied Catalysis A: General, 246: 303-309.

[10] Burda, C., Chen, X., Narayanan, R., El-Sayed, M.A. (2005). Chemistry and Properties of Nanocrystals of Different Shapes. Chemical Reviews, 105: 1025-1102.
[11] Wang, C., Chen, L., Qi, Z. (2013). One-pot Synthesis of Gold Nanoparticles Embedded in Silica for Cyclohexane Oxidation. Catalysis Science \& Technology, 3: 1123-1128.

[12] Wu, P., Xiong, Z., Loh, K.P., Zhao, X.S. (2011). Selective Oxidation of Cyclohexane over Gold Nanoparticles Supported on Mesoporous Silica Prepared in the Presence of Thioether Functionality. Catalysis Science \& Technology, 1: 285-294.

[13] Bradley, J.S. In: Schmidt G., editor. (1994). Clusters and Colloids from Theory to Applications, VCH, Weinheim, Germany.

[14] Liu, X., Conte, M., Sankar, M., He, Q., Murphy, D.M., Morgan, D., Jenkins, R.L., Knight, D., Whiston, K., Kiely, C.J., Hutchings, G.J. (2015). Liquid Phase Oxidation of Cyclohexane Using Bimetallic Au-Pd/MgO Catalysts. Applied Catalysis A: General, 504: 373-380.

[15] Mahdavi, V., Hasheminasab, H.R. (2015). Liquid-phase Efficient Oxidation of Cyclohexane over Cobalt Promoted VPO Catalyst Using Tert-butylhydroperoxide. Journal of the Taiwan Institute of Chemical Engineers, 51: 53-62.

[16] Makgwane, P.R., Ray, S.S. (2014). Efficient Room Temperature Oxidation of Cyclohexane over Highly Active Hetero-mixed $\mathrm{WO}_{3} / \mathrm{V}_{2} \mathrm{O}_{5}$ Oxide Catalyst. Catalysis Communications, 54: 118-123.

[17] Bellifa, A., Choukchou-Braham, A., Kappenstein, C., Pirault-Roy, L. (2014). Preparation and Characterization of MTiX for the Catalytic Oxidation of Cyclohexane. RSC Advances, 4: 22374-22379.

[18] Hayati, F., Chandren, S., Hamdan, H., Nur, H. (2014). The Role of Ti and Lewis Acidity in Manganese Oxide Octahedral Molecular Sieves Impregnated with Titanium in Oxidation Reactions. Bulletin of Chemical Reaction Engineering \& Catalysis, 9: 28-38.

[19] Carabineiro, S.A.C., Martins, L.M., AvalosBorja, M., Buijnsters, J.G., Pombeiro, A.J.L., Figueiredo, J.L. (2013). Gold Nanoparticles Supported on Carbon Materials for Cyclohexane Oxidation with Hydrogen Peroxide. Applied Catalysis A: General, 467: 279-290.

[20] Huang, G., Shen, L., Luo, Z.C., Hu, Y.D., Guo, Y.A., Wei, S.J. (2013). Use of A Boehmite Immobilized Cobalt Tetra(4-carboxyl) Phenylporphyrin Catalyst for the Aerobic Oxidation of Cyclohexane to Ketone and Alcohol. $\mathrm{Ca}$ talysis Communications, 32: 108-112.

[21] Lu, X.H., Yuan, H.X., Lei, J., Zhang, J.L., Yu, A.A., Zhou, D., Xia, Q.H. (2012). Selective Oxidation of Cyclohexane to KA-oil with Oxygen over Active $\mathrm{Co}_{3} \mathrm{O}_{4}$ in A Solvent-free System. Indian Journal of Chemistry, 51A: 420427. 
[22] Bernas, A., Kumar, N., Laukkanen, P., Vayrynen, J., Salmi, T., Murzin, D.Y. (2004). Influence of Ruthenium Precursor on Catalytic Activity of $\mathrm{Ru} / \mathrm{Al}_{2} \mathrm{O}_{3}$ Catalyst in Selective Isomerization of Linoleic Acid to Cis-9,trans-11and Trans-10,cis-12-conjugated Linoleic Acid. Applied Catalysis A: General, 267: 121-133.

[23] Perkas, N., Minh, D.P., Gallezot, P., Gedanken, A., Besson, M. (2005). Platinum and Ruthenium Catalysts on Mesoporous Titanium and Zirconium Oxides for the Catalytic Wet Air Oxidation of Model Compounds. Applied Catalysis B: Environmental, 59: 121130 .

[24] Bergeret, G., Gallezot, P. (1997). In: Handbook of Heterogeneous Catalysis. Wiley-VCH, Weinheim.

[25] Coloma, F., Sepulveda-Escribano, A., Fierro, J.L., Rodriguez- Reinoso, F. (1997). Gas Phase Hydrogenation of Crotonaldehyde over Pt/Activated Carbon Catalysts: Influence of the Oxygen Surface Groups on the Support. Applied Catalysis A: General, 150: 165-183.

[26] Rekkab-Hammoumraoui, I., ChoukchouBraham, A., Pirault-Roy, L., Kappenstein, C. (2011). Catalytic Oxidation of Cyclohexane to Cyclohexanone and Cyclohexanol by TertButyl Hydroperoxide over Pt/oxide Catalysts. Bulletin of Materials Science, 34: 1127-1135.

[27] Kumar, R., Sithambaram, S., Suib, S.L. (2009). Cyclohexane Oxidation Catalyzed by Manganese Oxide Octahedral Molecular Sieves-Effect of Acidity of the Catalyst. Journal of Catalysis, 262: 304-313.

[28] Bellifa, A., Lahcene, D., Tchenar, Y.N., Choukchou-Braham, A., Bachir, R., Bedrane, S., Kappenstein, C. (2006). Preparation and Characterization of 20 wt.\% $\mathrm{V}_{2} \mathrm{O}_{5}-\mathrm{TiO}_{2}$ Catalyst Oxidation of Cyclohexane. Applied $\mathrm{Ca}$ talysis A: General, 305: 1-6.

[29] Zhao, R., Wang, Y., Guo, Y., Guo, Y., Liu, X., Zhang, Z., Wang, Y., Zhan, W., Lu, G. (2006). A Novel Ce/AlPO-5 Catalyst for Solvent-free Liquid Phase Oxidation of Cyclohexane by Oxygen. Green Chemistry, 8: 459-466.

[30] Wangcheng, Z., Guanzhong, L., Yanglong, G., Yun, G., Yanqin, W., Yunsong, W., Zhigang, Z., Xiaohui, L. (2008). Synthesis of Ceriumdoped MCM-48 Molecular Sieves and Its Catalytic Performance for Selective Oxidation of Cyclohexane. Journal of Rare Earths, 26: 515-522.

[31] Lu, G., Zhao, R., Qian, G., Qia, Y., Wang, X., Suo, J. (2004). A Highly Efficient Catalyst Au/MCM-41 for Selective Oxidation Cyclohexane Using Oxygen. Catalysis Letters, 97: 115118.
[32] Li, H., She, Y., Wang, T. (2012). Advances and Perspectives in Catalysts for Liquidphase Oxidation of Cyclohexane. Frontiers of Chemical Science and Engineering, 6: 356368.

[33] Liu, Y., Tsunoyama, H., Akita, T., Xie, S., Tsukuda, T. (2011). Aerobic Oxidation of Cyclohexane Catalyzed by Size-Controlled Au Clusters on Hydroxyapatite: Size Effect in the Sub-2 nm Regime. ACS Catalysis, 1: 2-6.

[34] Rekkab-Hammoumraoui, I., BenabadjiSoulimane, R., El Korso-Hamza Reguig, S., Choukchou-Brabam, A., Bachir, R. (2010). Preparation and Characterization of $\mathrm{X}$ wt$\% \mathrm{Ru} / \mathrm{Al}_{2} \mathrm{O}_{3}$ Catalysts for Cyclohexane Oxidation Using Tert-butyl Hydroperoxide. Research Journal of Pharmaceutical, Biological and Chemical Sciences, 1: 240-239.

[35] Sooknoi, T., Limtrakul, J., (2002). Activity Enhancement by Acetic Acid in Cyclohexane Oxidation Using Ti-containing Zeolite Catalyst. Applied Catalysis A: General, 233: $227-$ 237.

[36] Adam, F., Wong, J., Ng, E. (2013). Fast Catalytic Oxidation of Phenol over Iron Modified Zeolite L Nanocrystals. Chemical Engineering Journal, 214: 63-67.

[37] Arends, I.W.C.E., Sheldon, R.A. (2001). Activities and Stabilities of Heterogeneous Catalysts in Selective Liquid Phase Oxidations: Recent Developments. Applied Catalysis A: General, 212: 175-187.

[38] Fraile, J.M., Garcia, J.I., Mayoral, J.A., Vispe, E. (2001). Effect of the Reaction Conditions on the Epoxidation of Alkenes with Hydrogen Peroxide Catalyzed by SilicaSupported Titanium Derivatives. Journal of Catalysis, 204: 146-156.

[39] Busca, G., Finocchio, E., Ramis, G., Ricchiardi, G. (1996). On the Role of Acidity In Catalytic Oxidation. Catalysis Today, 32: 133-143.

[40] Conte, M., Liu, X., Murphy, D.M., Whiston, K., Hutchings, G.J. (2012). Cyclohexane Oxidation Using $\mathrm{Au} / \mathrm{MgO}$ : An Investigation of the Reaction Mechanism. Physical Chemistry Chemical Physics, 14: 16279-16285.

[41] Yuan, H.X., Xia, Q.H., Zhan, H.J., Lu, X.H., Su, K.X. (2006). Catalytic Oxidation of Cyclohexane to Cyclohexanone and Cyclohexanol by Oxygen in A Solvent-free System over Metal-containing ZSM-5 Catalysts. Applied Catalysis A: General, 304: 178-184.

[42] Kharkova, T.V., Arest-Yakubovich, I.L., Lipes, V.V. (1989). Kinetic Model of the Liquidphase Oxidation of Cyclohexane. I. Homogeneous Proceedings of the Process. Kinetics and Catalysis, 30: 954-958. 
[43] Loncarevic, D., Krstic, J., Bankovic, P., Anic, S., Cupic, Z. (2007). Temperature Dependence of Catalytic Cyclohexane Partial Oxidation in A Polytetrafluoroethylene Reactor. Russian Journal of Physical Chemistry A., 81: 13981401.

[44] Akhrem, A.A., Metelitsa, D.I., Skurko, M.E., (1975). Chemical Model of the Enzyme System for Hydroxylating Cyclohexane. Bioorganic Chemistry, 4: 307-316.

[45] Larsen, R.G., Saladino, A.C., Hunt, T.A., Mann, J.E., Xu, M., Grassian, V.H., Larsen, S.C. (2001). A Kinetic Study of the Thermal and Photochemical Partial Oxidation of Cyclohexane with Molecular Oxygen in Zeolite Y. Journal of Catalysis, 204: 440-449.

[46] Mahajani, S.M., Sharma, M.M., Sridhar, T. (1999). Uncatalyzed Oxidation of Cyclohexene. Chemical Engineering Science, 54: 39673976 .

[47] Suresh, A.K., Sridhar, T., Potter, O.E. (1988). Autocatalytic Oxidation of CyclohexaneModeling Reaction Kinetics. AlChE Journal, 34: 69-80.

[48] Wang, J., Zhao, H., Zhang, X., Liu, R., Hu, Y. (2008). Oxidation of Cyclohexane Catalyzed by TS-1 in Ionic Liquid with Tert-butylhydroperoxide. Chinese Journal of Chemical Engineering, 16: 373-375.
[49] Selvam, P., Mohapatra, S.K. (2004). Synthesis, Characterization and Catalytic Properties of Mesoporous TiHMA Molecular Sieves: Selective Oxidation of Cycloalkanes. Microporous and Mesoporous Materials, 73: 137-149.

[50] Liu, X., He, J., Yang, L., Wang, Y., Zhang, S., Wang, W., Wang, J. (2010). Liquid-phase Oxidation of Cyclohexane to Cyclohexanone over Cobalt-Doped SBA-3. Catalysis Communications, 11: 710-714.

[51] Dapurkar, S.E., Sakthivel, A., Selvam, P. (2004). Mesoporous VMCM-41: Highly Efficient and Remarkable Catalyst for Selective Oxidation of Cyclohexane to Cyclohexanol. Journal of Molecular Catalysis A: Chemical, 223: 241-250.

[52] Wu, P., Bai, P., Loh, K.P., Zhao, X.S. (2010). Au Nanoparticles Dispersed on Functionalized Mesoporous Silica for Selective Oxidation of Cyclohexane. Catalysis Today, 158: 220-227.

[53] Aboelfetoh, E.F., Fechtelkord, M., Pietschnig, R. (2010). Structure and Catalytic Properties of $\mathrm{MgO}$-supported Vanadium Oxide in the Selective Oxidation of Cyclohexane. Journal of Molecular Catalysis A: Chemical, 318: 51-59.

[54] Silva, F.P., Jacinto, M.J., Landers, R., Rossi, L.M. (2011). Selective Allylic Oxidation of Cyclohexene by a Magnetically Recoverable Cobalt Oxide Catalyst. Catalysis Letters, 141: 432-437 